\title{
The association of serum metabolites in the transition period with milk production and early-lactation reproductive performance
}

\author{
N. Chapinal, ${ }^{*} \dagger^{1}$ M. E. Carson, ${ }^{\star}$ S. J. LeBlanc, ${ }^{*}$ K. E. Leslie, ${ }^{*}$ S. Godden,‡ M. Capel,§ J. E. P. Santos,\# \\ M. W. Overton,II and T. F. Duffield* \\ *Department of Population Medicine, University of Guelph, Ontario, Canada, N1G 2W1 \\ †Animal Welfare Program, University of British Columbia, BC, Canada, V6T 1 Z4 \\ $\ddagger$ Department of Veterinary Population Medicine, University of Minnesota, St. Paul 55108 \\ §Perry Veterinary Clinic, Perry, NY 14530 \\ \#Department of Animal Science, University of Florida, Gainesville 32611 \\ IIDepartment of Population Health, University of Georgia, Athens 30602
}

\begin{abstract}
The objective was to examine the associations of peripartum concentrations of nonesterified fatty acids (NEFA), $\beta$-hydroxybutyrate (BHBA), and calcium with milk production in early lactation and pregnancy at the first artificial insemination (AI) across different management systems. Fifty-five Holstein freestall dairy herds located across the United States and Canada were visited weekly for blood sample collection from 2,365 cows. For each week of sampling (from wk -1 through wk 3 relative to calving) and for each metabolite, serum concentrations were dichotomized at various thresholds to identify the thresholds with the best negative associations with milk production and pregnancy at first AI. These thresholds were used to categorize the serum concentrations into higher and lower risk categories. Repeated-measures ANOVA and multivariable logistic regression were conducted for milk production and pregnancy at the first AI data, respectively, considering cow as the experimental unit and herd as a random effect. In the week before calving, serum NEFA $\geq 0.5 \mathrm{mEq} / \mathrm{L}, \mathrm{BHBA} \geq 600 \mu \mathrm{mol} / \mathrm{L}$, and calcium $\leq 2.1$ $\mathrm{mmol} / \mathrm{L}$ were associated with 1.6 to $3.2 \mathrm{~kg} / \mathrm{d}$ milk loss across the first 4 Dairy Herd Improvement Association (DHIA) milk tests. High levels of NEFA and BHBA in wk 1 and 2 after calving $(\geq 0.7$ and $\geq 1.0 \mathrm{mEq} / \mathrm{L}$ for NEFA, and $\geq 1,400$ and $\geq 1,200 \mu \mathrm{mol} / \mathrm{L}$ for BHBA), and low levels of calcium $(\leq 2.1 \mathrm{mmol} / \mathrm{L})$ in wk 1,2 and 3 after calving were associated with milk loss at the first DHIA milk test. Serum concentrations of NEFA and BHBA were not associated with pregnancy at first AI in any sampling week, whereas calcium $<2.2$ to 2.4 $\mathrm{mmol} / \mathrm{L}$ from wk 1 through wk 3 postpartum were associated with reduced pregnancy at first AI. In conclu-
\end{abstract}

Received July 13, 2011.

Accepted November 9, 2011.

${ }^{1}$ Corresponding author: nchapinal@yahoo.com sion, high serum concentrations of NEFA, BHBA, and low concentrations of calcium around parturition were associated with early lactation milk loss, and low calcium concentration around parturition was associated with impaired early lactation reproduction.

Key words: nonesterified fatty acid, $\beta$-hydroxybutyrate, hypocalcemia, negative energy balance

\section{INTRODUCTION}

During the transition period, defined as the period from 3 wk before to 3 wk after calving (Grummer, 1995), an increase in energy demand occurs that is caused by fetal growth and the onset of the lactation, at a time when DMI often decreases. Consequently, virtually all high-producing dairy cows go through some degree of negative energy balance (NEB) immediately following calving (Herdt, 2000). The mean duration of NEB postcalving is $45 \mathrm{~d}$, with a standard deviation of $21 \mathrm{~d}$ (Grummer and Rastani, 2004).

The initiation of lactation alters metabolism to supply the mammary gland with the nutrients necessary for milk synthesis (Bauman and Currie, 1980). If cows are unable to alter their energy metabolism rapidly enough for milk synthesis, they either produce milk below their capability or are susceptible to metabolic disorders. Body fat stores are mobilized into the bloodstream in the form of NEFA and contribute to overall energy requirements during early lactation. Feed DMI and serum NEFA concentrations usually have an inverse relationship (Overton and Waldron, 2004). Glucose, insulin, epinephrine, norepinephrine, and growth hormone are the major controls of lipid metabolism (Bauman and Currie, 1980; Herdt, 2000). When serum insulin concentrations are reduced, lipolysis increases, releasing more NEFA into the blood. An increase in stress can stimulate increases in lipolysis through epinephrine secreted from the adrenal medulla. The liver removes a large portion of the NEFA circulating in the 
bloodstream by metabolizing NEFA into ketone bodies, such as BHBA, or re-esterifying them into triglycerides (Herdt, 2000).

Previous studies have reported associations between metabolite concentrations and milk production. Increased concentrations of ketone bodies in milk in early lactation have been associated with a reduction in milk yield (Dohoo and Martin, 1984). Duffield et al. (2009) reported early and overall lactation milk losses associated with elevations in serum BHBA in the first week after calving. Elevated serum BHBA in the second week after calving was associated with milk losses in early lactation but higher overall milk production. Recently, Ospina et al. (2010b) sampled a cohort of animals within 2 wk before calving for serum NEFA concentration and a cohort of animals within 2 wk after calving for serum NEFA and BHBA. Elevated precalving NEFA in cows and heifers, and postcalving NEFA and BHBA in cows were associated with overall milk loss. Interestingly, elevated postcalving NEFA and BHBA in primiparous animals were associated with an overall milk increase.

Negative energy balance has been linked to impaired reproductive performance. Cows with elevated NEFA within 2 wk before calving and with elevated NEFA and BHBA within 2 wk after calving are less likely to become pregnant in early lactation (Walsh et al., 2007; Ospina et al., 2010b). Reproductive performance can also be impaired due to uterine disease and delayed luteal activity, which in turn are associated with elevated levels of NEFA and BHBA (Hammon et al., 2006; Wathes et al., 2007).

The objective was to examine the associations of selected indicators of energy metabolism and calcium with milk production and pregnancy at first AI. The hypothesis was that cows with high serum NEFA and BHBA and low serum calcium concentration around parturition would have reduced milk production and decreased reproductive performance. This study is novel in assembling a representative sample from most of the major dairy regions of the United States and Canada and, in contrast to a recent large field study (Ospina et al., 2010b), it follows the same cohort of animals through the peripartum period.

\section{MATERIALS AND METHODS}

Fifty-five Holstein freestall dairy herds located across the United States and Canada were selected based on the herd managers' willingness to participate in the study. Study herds were required to be subscribed to a milk recording service (DHIA) and to have a minimum of 100 milking cows (range: 100 to 6,000 cows). Selection of herds was not random and was a convenience sample of herds within a 2-h drive of one of the authors' study sites that the investigator expected to comply with accurate record keeping. The continent was divided into 4 regions in which herds were recruited: Midwest (MN and WI; $\mathrm{n}=556$ cows from 17 herds), Northeast (NY and Ontario; $n=662$ cows from 20 herds), Southeast (FL, GA, NC, SC, and VA; $\mathrm{n}=494$ cows from 10 herds), and West (CA; $\mathrm{n}=653$ from 8 herds). The median number of cows sampled per herd was 36 (range of 21 to 91). This is the same data set used in Chapinal et al. (2011) and details on sample size calculations are reported in that paper.

Data were collected from May 2006 to January 2007. Technicians visited each herd weekly, at the same time on the same day of the week. Cows and heifers were enrolled beginning $10 \mathrm{~d}$ before expected calving date using lists generated from herd management software programs (DairyComp 305, Valley Agricultural Software, Tulare, CA; PCDART, Dairy Records Management Systems, Raleigh, NC), with subsequent visits in wk 1, 2, and 3 after calving. During each visit, a 10-mL blood sample was collected from the coccygeal vessels into an evacuated sterile tube without anticoagulant (Vacutainer, Becton Dickinson, Franklin Lakes, NJ). The samples were kept chilled and allowed to clot. Blood was centrifuged and the serum was separated and stored at $-20^{\circ} \mathrm{C}$ within $8 \mathrm{~h}$ of collection. Body condition score was assigned at enrollment, on a scale of 1 (thin) to 5 (obese), using increments of 0.25 (Wildman et al., 1982). Herd managers recorded disease events on a standard form. Technicians educated herd managers, through the use of verbal discussion and information sheets, on case definitions of disease events to standardize the information collected. Serum was sent to the Animal Health Laboratory, University of Guelph, for analyses of NEFA, BHBA, and total calcium concentrations. All biochemical tests were conducted on an automated analyzer (Hitachi 911 Analyzer, Randox, Laval, Quebec, Canada), using reagents supplied by Randox. Serum that was sent to Guelph from distant regions was packed in coolers to maintain $-20^{\circ} \mathrm{C}$ and shipped by overnight courier.

Dairy Herd Improvement test-day milk production data and pregnancy at the first AI were retrieved from herds using on-farm Dairy Comp 305 (Valley Agricultural Software) or PCDART (Dairy Records Management Systems) software and assembled in an Access database (Microsoft Corp., Redmond, WA) The first 4 test-day milk production records were collected for each cow to describe approximately the first $120 \mathrm{~d}$ of lactation.

\section{Data Analysis}

Milk Production. Univariable analyses were first performed to assess the association between milk pro- 
duction across the 4 DHIA tests and different categorical variables (region, season of calving, parity, BCS, postcalving clinical disease, and occurrence of dystocia and twins) by using a mixed model (PROC MIXED; SAS Institute Inc., Cary, NC) with repeated measures within cows (nested within herd and region) and considering herd (nested within region) as a random effect. A first-order autoregressive covariance structure was chosen among others (such as unstructured or Toeplitz), based on the lowest Akaike's information criterion. Parity was categorized into primiparous and multiparous cows. Body condition score was categorized as thin $(\leq 3.0)$, moderate $(3.25-3.75)$, or fat $(\geq 4.0)$. Seasons of calving were divided into warm months (May through August) and cool months (September through January). A binary disease variable was created and coded 1 if a cow was diagnosed with at least one of retained placenta, milk fever, metritis, or displaced abomasum before 30 DIM. Variables that were not associated with milk production in the univariable analysis $(P>0.20)$ were not considered further.

For each week of sampling (from wk -1 to wk 3 relative to calving) and for each metabolite, a series of thresholds of concentrations was created, ranging from 0.2 to $1.4 \mathrm{mEq} / \mathrm{L}$ with $0.1 \mathrm{mEq} / \mathrm{L}$ increases for NEFA, from 400 to $2,000 \mu \mathrm{mol} / \mathrm{L}$ with $200 \mu \mathrm{mol} / \mathrm{L}$ increases for BHBA, and 1.8 to $2.6 \mathrm{mmol} / \mathrm{L}$ with $0.1 \mathrm{mmol} / \mathrm{L}$ increases for calcium. Hierarchical dummy variables were created, designating a value of 1 for the group considered at higher risk (samples at or above the threshold for NEFA and BHBA, and at or below the threshold for calcium) and a value of 0 otherwise. To maintain temporal associations between metabolites and milk production, only serum samples collected before the first DHIA milk test were considered.

Differences in milk production across the 4 DHIA tests between the high and low risk metabolite concentration groups were tested by using mixed models (PROC MIXED; SAS Institute Inc.) with repeated measures within cows (nested within herd and region) and considering herd (nested within region) as a random effect. A Toeplitz covariance structure was chosen based on the lowest Akaike's information criterion. Separate multivariable mixed models were first created for each metabolite and week of sampling, including the dichotomized metabolite (1 dummy variable tested at a time), the linear and quadratic effect of DIM at DHIA test, the categorical covariates (region, season of calving, parity, BCS, disease that occurred before the blood sample being tested was obtained, and occurrence of dystocia and twins) that were significant in the univariable analyses, and the biologically plausible 2 -way interactions. Covariates and interactions were removed from the final model if $P>0.05$ by manual backward selection. Because disease events occurred after the precalving samples were obtained, the precalving models were built with disease included or excluded to investigate the associations of precalving metabolites with milk production, with and without knowledge of future disease events. Similar models, but without repeated measures, were used to assess differences in milk production at the first DHIA test only between the high and low risk groups, testing one dummy variable at a time. From each model, the metabolite threshold for the dummy variable having a negative $\beta$ coefficient and the lowest $P$-value was chosen as the optimal threshold for defining the group at risk based on milk production loss. For each week of blood sampling, the selected thresholds for the 3 metabolites were combined in mixed models similar to the models described previously. These models included both the current week of interest as well as the previous weeks in postcalving models. Spearman correlation coefficients between the different selected dummy variables were calculated to avoid submitting highly correlated variables to the same model. The correlation coefficients were $\leq 0.30$ in all cases. Residuals were examined after each model to verify normality and homogeneity of variances as well as to detect possible outliers and influential observations.

Pregnancy at the First AI. For each week of sampling and for each metabolite, the same series of thresholds of concentrations as described above was tested for association with pregnancy at the first AI. Initial screening of metabolite thresholds for simple associations with pregnancy at the first AI was performed with Chi-squared tests using $2 \times 2$ contingency tables. Among associations with $P<0.05$, the highest combined sensitivity and specificity was chosen as the optimal threshold and was used to categorize the concentrations of NEFA, BHBA, and calcium into high and low risk groups. Univariable associations between categorical cow-level covariates (listed above) and pregnancy at the first AI were tested with Chi-squared tests. For each week of sampling, dichotomized metabolites concentrations, significant covariates in the univariable analysis and the biologically plausible 2-way interactions were submitted to multivariable logistic regression (PROC GLIMMIX), using a binary distribution and logit link function, and herd as a random effect. Covariates and interactions were removed from the final model if $P$ $>0.05$ by manual backward selection. The predicted probabilities of pregnancy were estimated from the model (LSMEANS statement). Residuals were examined after each model to detect possible outliers and influential observations. 
Table 1. Descriptive data on DHIA test-day milk production $(\mathrm{kg} / \mathrm{d})$ from 1,919 Holstein cows in 45 herds in 4 regions of Canada and the United States in 2006-2007

\begin{tabular}{|c|c|c|c|c|c|}
\hline \multirow[b]{2}{*}{ Test-day } & \multirow{2}{*}{$\begin{array}{c}\text { Samples } \\
\text { (no.) }\end{array}$} & \multicolumn{2}{|c|}{ DIM } & \multicolumn{2}{|c|}{ Milk production } \\
\hline & & Mean & $\mathrm{SD}$ & Mean & $\mathrm{SD}$ \\
\hline 1 & 1,842 & 20 & 11 & 34.8 & 11.4 \\
\hline 2 & 1,836 & 52 & 15 & 40.1 & 10.3 \\
\hline 3 & 1,699 & 84 & 19 & 40.1 & 9.7 \\
\hline 4 & 1,748 & 117 & 24 & 38.7 & 9.2 \\
\hline
\end{tabular}

\section{RESULTS}

From the 55 herds selected, 2,365 cows were sampled across the 4 study regions. Only 45 herds recorded monthly DHIA milk production data. In total, 102 cows within the 45 herds were discarded because they were sold or culled before the first DHIA milk test. As a result, a total of 1,919 cows and 7,125 DHIA test-day records were considered in the milk production analysis. A total of 60,420 , and 781 blood samples collected in wk 1,2 , and 3 , respectively, from the 1,919 cows were not included in the analyses because data were missing or the samples were collected after the first DHIA milk test. Data on pregnancy at first AI were available for 48 herds only. In total, 110 cows within the 48 herds were sold or culled after calving and before pregnancy data at first AI were available. As a result, 2,069 cows were considered in the analysis. A total of 20, 23, and 79 blood samples collected in wk 1, 2 and 3, respectively, from the 2,069 cows were not included in the analyses because the data were missing.

\section{Milk Production}

Data on test-day production in the 45 herds are shown in Table 1. In the univariable analyses, no significant differences in milk production were observed across the 4 DHIA tests among regions or between the 2 calving seasons, whereas DIM at DHIA test, BCS, parity, postcalving clinical disease, and dystocia were associated with differences in milk production. Cows with $\mathrm{BCS} \geq 4.0$ in the week before calving produced 1.4 $\pm 0.5 \mathrm{~kg} / \mathrm{d}$ more milk compared with cows with BCS $\leq 3.0(P=0.006)$. Multiparous cows (59\% of the cows sampled) produced $8.6 \pm 0.3 \mathrm{~kg} / \mathrm{d}$ more milk compared with primiparous cows $(P<0.001)$. Cows with at least one disease event after calving (25.5\% of the cows) produced $1.5 \pm 0.4 \mathrm{~kg} / \mathrm{d}$ less milk $(P<0.001)$, whereas cows with difficulties at calving ( $10.5 \%$ of the cows) produced $2.4 \pm 0.6 \mathrm{~kg} / \mathrm{d}$ less milk $(P<0.001)$. Giving birth to twins $(3.2 \%$ of the cows) had no effect on milk production $(P=0.2)$.

Higher concentrations of NEFA and BHBA and lower concentrations of calcium in the week before calving were associated with milk loss across the first 4 DHIA milk tests, when each metabolite was tested in a separate model (Table 2). The thresholds with the highest association with milk loss were NEFA $\geq 0.5 \mathrm{mEq} / \mathrm{L}$, $\mathrm{BHBA} \geq 600 \mu \mathrm{mol} / \mathrm{L}$, and calcium $\leq 2.1 \mathrm{mmol} / \mathrm{L}$ in the week before calving. A significant parity by NEFA $\geq 0.5$ $\mathrm{mEq} / \mathrm{L}$ interaction $(P=0.02)$ was observed such that the association between NEFA $\geq 0.5 \mathrm{mEq} / \mathrm{L}$ and milk loss was only significant in multiparous cows. Results were very similar when only the first DHIA test was considered. The models controlling for clinical disease that occurred after calving yielded very similar coefficient estimates, and interactions between disease and precalving metabolites concentrations were not significant in any case $(P>0.3)$.

When the 3 metabolites (dichotomized at the selected optimal thresholds) were combined in the same model for wk -1 relative to calving, only BHBA $\geq 600 \mu \mathrm{mol} / \mathrm{L}$ (estimate $=-1.5 \pm 0.4 \mathrm{~kg} / \mathrm{d} ; P<0.001)$ and calcium $\leq 2.1 \mathrm{mmol} / \mathrm{L}$ (estimate $=-2.9 \pm 0.4 \mathrm{~kg} / \mathrm{d} ; P<0.001)$ remained in the model after controlling for the effect of parity, DIM (linear and quadratic), and BCS. When only NEFA $\geq 0.5 \mathrm{mEq} / \mathrm{L}$ and BHBA $\geq 600 \mu \mathrm{mol} / \mathrm{L}$ were considered in the same model, a significant NEFA by parity interaction $(P=0.02)$ was observed. When the model was stratified by parity, only BHBA (estimate = $-1.7 \pm 0.6 \mathrm{~kg} / \mathrm{d} ; P=0.03)$ remained in the model in the case of primiparous cows, and both NEFA (estimate $=-1.2 \pm 0.5 \mathrm{~kg} / \mathrm{d} ; P=0.02$ ) and BHBA (estimate $=$ $-1.4 \pm 0.5 \mathrm{~kg} / \mathrm{d} ; P=0.006)$ remained in the model in the case of multiparous cows.

High serum concentrations of NEFA and BHBA in wk 1,2, and 3 after calving were not associated with milk loss when all 4 DHIA tests were considered. In fact, low concentrations of these metabolites, particularly in wk 1 and 2 after calving, were associated with milk production loss over the 4 DHIA tests. All NEFA thresholds below 0.5 and $0.7 \mathrm{mEq} / \mathrm{L}$ in wk 1 and 2 after calving, respectively, and all BHBA thresholds below $800 \mu \mathrm{mol} / \mathrm{L}$ in wk 1 and 2 after calving were associated with higher milk yield (i.e., cows with NEFA and BHBA concentrations at or above each of those thresholds produced more milk than cows with concentrations below the same thresholds). Calcium $\leq 2.1 \mathrm{mmol} / \mathrm{L}$ in 
Table 2. Milk losses across the first 4 DHIA tests in lactation associated with serum metabolites sampled in wk -1 relative to calving for 1,919 Holstein cows ${ }^{1}$

\begin{tabular}{lcccc}
\hline Variable & $\begin{array}{c}\text { Proportion of animals in } \\
\text { the high-risk group }(\%)\end{array}$ & $\begin{array}{c}\text { Estimate } \\
(\mathrm{kg} \text { of milk/d) }\end{array}$ & $\mathrm{SE}$ & $P$-value \\
\hline $\mathrm{NEFA} \geq 0.5 \mathrm{mEq} / \mathrm{L}^{2}$ & 25 & -1.6 & 0.5 & 0.001 \\
$\mathrm{BHBA} \geq 600 \mu \mathrm{mol} / \mathrm{L}$ & 26 & -1.7 & 0.4 & $<0.0001$ \\
$\mathrm{Calcium} \leq 2.1 \mathrm{mmol} / \mathrm{L}$ & 7 & -3.2 & 0.8 & $<0.0001$ \\
\hline
\end{tabular}

${ }^{1}$ Each metabolite was tested in a separate model, controlling for the effect of BCS before calving, the linear and quadratic effect of DIM, parity, and the random effect of herd. Metabolite concentrations were dichotomized at different thresholds and only the threshold with the highest association with milk loss is shown.

${ }^{2}$ Parity by NEFA interaction $(P=0.02)$. The association of NEFA $\geq 0.5 \mathrm{mEq} / \mathrm{L}$ was only significant for multiparous cows.

wk 2 ( $8 \%$ of the cows) and wk 3 ( $4 \%$ of the cows) was associated with milk loss across the 4 DHIA tests of $2.6 \pm 0.6$ and $3.5 \pm 0.9 \mathrm{~kg} / \mathrm{d}$, respectively $(P<0.001)$.

When only the first DHIA milk test was considered (Table 3), high levels of NEFA and BHBA in wk 1 and 2 after calving, and low levels of calcium in wk 1 , 2 , and 3 after calving were associated with milk loss when each metabolite was tested in a separate model. An interaction was found between NEFA concentration and parity in wk 1 after calving $(P=0.04)$, such that high NEFA concentrations were only associated with milk loss in multiparous cows.

When the 3 metabolite concentrations measured in wk -1 and wk 1 relative to calving (dichotomized at the selected optimal thresholds) were combined in the same model, considering only the first DHIA milk test, only calcium $\leq 2.1 \mathrm{mmol} / \mathrm{L}$ (estimate $=-2.6 \pm 0.5$ $\mathrm{kg} / \mathrm{d} ; P<0.001)$ measured in wk 1 remained in the model after controlling for the effect of parity and DIM (linear and quadratic). When only NEFA and BHBA measured in wk -1 and wk 1 were considered, only BHBA $\geq 1,400 \mu \mathrm{mol} / \mathrm{L}$ measured in wk 1 remained in the model in the case of primiparous cows (estimate $=-2.9 \pm 1.0 \mathrm{~kg} / \mathrm{d} ; P=0.004)$, and only NEFA $\geq 0.7$ $\mathrm{mEq} / \mathrm{L}$ measured in wk 1 remained in the model in the case of multiparous cows (estimate $=-1.6 \pm 0.6 \mathrm{~kg} / \mathrm{d}$; $P=0.01$ ), after controlling for the effect of DIM (linear and quadratic).

When the 3 metabolite concentrations measured in wk -1 , wk 1 , and wk 2 relative to calving (dichotomized at the selected optimal thresholds) were combined in the same model, considering only the first DHIA milk test, only precalving BHBA (estimate $=-1.5 \pm 0.6$ $\mathrm{kg} / \mathrm{d} ; P<0.001)$ and calcium measured in wk 1 and wk 2 relative to calving remained in the model (estimate $=-2.0 \pm 0.6$ and $3.9 \pm 1.0 \mathrm{~kg} / \mathrm{d}$, respectively; $P<$ 0.001) after controlling for the effect of parity, DIM (linear and quadratic), and disease that occurred before

Table 3. Milk losses at the first DHIA test in lactation associated with serum metabolites sampled in wk 1 (n $=1,858)$, wk $2(\mathrm{n}=1,499)$, and wk $3(\mathrm{n}=1,138)$ relative to calving

\begin{tabular}{lcccc}
\hline Metabolite & $\begin{array}{c}\text { Proportion of animals in } \\
\text { the high-risk group }(\%)\end{array}$ & $\begin{array}{c}\text { Estimate } \\
(\mathrm{kg} \text { of milk/d) }\end{array}$ & $\mathrm{SE}$ & $P$-value \\
\hline Wk 1 after calving & & & & \\
NEFA $\geq 0.7 \mathrm{mEq} / \mathrm{L}^{3}$ & 41 & -1.8 & 0.6 & 0.001 \\
BHBA $\geq 1,400 \mu \mathrm{mol} / \mathrm{L}$ & 12 & -2.4 & 0.6 & $<0.001$ \\
Calcium $\leq 2.1 \mathrm{mmol}^{2}$ & 23 & -2.6 & 0.5 & $<0.001$ \\
Wk 2 after calving & & -1.7 & 0.8 & 0.03 \\
NEFA $\geq 1.0 \mathrm{mEq} / \mathrm{L}$ & 12 & -1.5 & 0.6 & 0.01 \\
BHBA $\geq 1,200 \mu \mathrm{mol} / \mathrm{L}$ & 20 & -4.8 & 1.0 & $<0.001$ \\
Calcium $\leq 2.1 \mathrm{mmol}^{4} \mathrm{~L}$ & 8 & -7.1 & 1.6 & $<0.001$ \\
Wk 3 after calving & & & & \\
Calcium $\leq 2.1 \mathrm{mmol} / \mathrm{L}$ & 4 & &
\end{tabular}

${ }^{1}$ Each metabolite was tested in a separate model. Metabolites concentrations were dichotomized at different thresholds and only the threshold with the highest association with milk loss is shown.

${ }^{2}$ Controlling for the linear and quadratic effect of DIM, parity, and the random effect of herd.

${ }^{3}$ Parity by NEFA interaction $(P=0.04)$. The association of NEFA $\geq 0.7 \mathrm{mEq} / \mathrm{L}$ was only significant for multiparous cows.

${ }^{4}$ Controlling for the linear and quadratic effect of DIM, parity, BCS before calving, clinical diseases that occurred before blood sampling, and the random effect of herd.

${ }^{5}$ Controlling for the effect of parity, clinical diseases that occurred before blood sampling, and the random effect of herd. 
the blood sample was collected. When only NEFA and BHBA measured in wk -1 , wk 1 , and wk 2 were considered, none of the metabolites remained in the model.

\section{Pregnancy at First Al}

Body condition score, postcalving clinical disease, and dystocia were associated with the odds of pregnancy at first AI in univariable analyses. Cows classified as thin or moderate BCS had lower odds of pregnancy at first AI than cows classified as fat [odds ratio $(\mathbf{O R})=0.54$; confidence limits $(\mathbf{C L})=0.40,0.73$, and $\mathrm{OR}=0.71$; $\mathrm{CL}=0.56,0.91$, for thin and moderate, respectively; $P$ $=0.002]$. The occurrence of postcalving clinical diseases $(\mathrm{OR}=0.60 ; \mathrm{CL}=0.48,0.77 ; P=0.001)$ and dystocia $(\mathrm{OR}=0.71 ; \mathrm{CL}=0.52,0.98 ; P=0.03)$ decreased the odds of pregnancy.

The initial screening showed no association between NEFA and BHBA concentrations and the odds of pregnancy at first AI. Higher calcium concentrations from wk -1 through wk 3 relative to calving were associated with increased odds of pregnancy. The optimal thresholds ranged from 2.2 to $2.4 \mathrm{mmol} / \mathrm{L}$, with 18 to $44 \%$ of the animals at or below the threshold. Yet, the specificity associated with the optimal thresholds was low, ranging from 19 to $44 \%$, whereas the sensitivity ranged from 63 to $87 \%$. After controlling for parity, BCS, and disease that occurred before blood sampling, the odds of conceiving was 1.5 times higher for cows with precalving calcium $>2.3 \mathrm{mmol} / \mathrm{L}(\mathrm{CL}=1.1,2.0$; $P=0.005$ ), and 1.3 times higher for cows with calcium $>2.2 \mathrm{mmol} / \mathrm{L}$ in wk $1,>2.3 \mathrm{mmol} / \mathrm{L}$ in wk 2 , and $>2.4$ $\mathrm{mmol} / \mathrm{L}$ in wk 3 relative to calving $(\mathrm{CL}=1.0,1.6 ; P$ $\leq 0.03)$. The predicted probabilities of pregnancy were 26 to $29 \%$ and 35 to $36 \%$ for cows with low and high calcium serum concentrations, respectively.

\section{DISCUSSION}

This study was a large, multi-region analysis of the association of serum metabolites in the transition period with milk production and early lactation reproductive performance on commercial dairies. Although the study herds were a convenience sample, the results are likely applicable to cows in freestall dairies in general because of the variety of management conditions represented. Cows that were culled before the first DHIA test or before first AI could not be included in the respective analyses. Although such cows were likely less healthy than those remaining in the analyses, the incidence of removal from the herd in early lactation (approximately $5 \%$ ) is similar to that reported for modern dairy herds (Dechow and Goodling, 2008).

\section{Milk Production}

The majority of the DHIA test-day samples were collected in the summer and fall for Northeast and Midwest herds, whereas the Southeast and Western herds were sampled from fall into early winter. The difference in season of sampling was due to available labor at the trial sites. Milk yield did not differ among regions. Other studies report differences in milk production among regions in the United States. Losinger and Heinrichs (1996) found that Western herds had a higher rolling average milk production than herds in the Midwest, the Northeast, and the Southeast. Ely et al. (2003) found that cows in the southeast produced less milk in comparison to cows in the Midwest and northeast, and they speculated these results were driven by environmental factors such as heat stress in the southeast. The majority of cows in the Southeast and Western regions being test sampled in the late fall and early winter for this study may explain why no regional difference was found.

In the current study, cows with precalving BCS $\geq 4.0$ produced more milk compared with cows with BCS $\leq 3.0$. Other studies have found similar patterns of overconditioned cows producing more milk in early lactation (Domecq et al., 1997; Duffield et al., 1999). Not surprisingly, developing one or more early lactation diseases negatively affected milk production. An association of disease in early lactation with reduced milk production before diagnosis and throughout subsequent lactation has been well documented (Edwards and Tozer, 2004; Sheldon et al., 2008).

We observed a relationship of precalving NEFA with milk production at the first test and through the first 4 test-days in multiparous cows. The optimal threshold of $\geq 0.5 \mathrm{mEq} / \mathrm{L}$ for predicting a reduction in milk yield was the same as that associated with an increased risk of displaced abomasum in LeBlanc et al. (2005) and Chapinal et al. (2011). The association was very similar when disease was accounted for in the model, showing that having elevated NEFA without subsequent clinical disease was still associated with decreased milk yield. Similarly, Ospina et al. (2010b) found that precalving serum NEFA concentrations $\geq 0.33 \mathrm{mEq} / \mathrm{L}$ resulted in a decrease of $683 \mathrm{~kg}$ in mature-equivalent 305-d milk yield in cows and heifers sampled within 2 wk before calving in 91 freestall herds in the northeastern United States. The increase in NEFA concentration typically starts approximately $5 \mathrm{~d}$ before calving (LeBlanc et al., 2005), which may explain why Ospina et al. (2010b) found a lower threshold, because their sampling timeframe was larger. On the other hand, a study looking at the effect of administrating propylene glycol before 
calving found lower NEFA concentrations in cows that received the treatment, but no significant difference was found in milk yields (Studer et al., 1993). With only 24 cows in that study, the statistical power may not have been high enough to find a difference. We found no association in the current study between higher NEFA concentrations and milk loss in primiparous cows. This supports a similar lack of association of clinical diseases (retained placenta and metritis) with milk production in primiparous dairy cows (Dubuc et al., 2011). This result might be explained in part by the concept of homeorhesis (Bauman and Currie, 1980), such that primiparous cows that already balance demands for growth with milk production might more readily shift metabolic partitioning in response to health challenges.

To our knowledge, this is the first study to report an association between precalving BHBA and milk loss. The optimal threshold of $\geq 600 \mu \mathrm{mol} / \mathrm{L}$ was slightly lower than the threshold of $\geq 800 \mu \mathrm{mol} / \mathrm{L}$ associated with an increased risk of displaced abomasum in Chapinal et al. (2011). When precalving NEFA and BHBA were tested together, both stayed in the model in the case of multiparous cows, but only BHBA remained in the case of primiparous cows. This result again suggests differences in physiological response between primiparous and multiparous cows as well as a potential use of precalving BHBA as a predictor of milk loss. This finding is very interesting because, in contrast to NEFA, ketones can be easily measured in the field (Carrier et al., 2004).

Lower NEFA and BHBA concentrations in wk 1, 2 , and 3 postcalving were associated with milk loss through the first 4 test-day milk samples, showing that a moderate degree of fat mobilization in early lactation may be critical to obtain high milk yields. Nevertheless, excessive magnitude or rate of mobilization of fat reserves will cause suboptimal metabolic performance and is likely an indicator of a reduced adaptive response to NEB. High concentrations of NEFA and BHBA after calving have been associated both with higher and lower overall milk production. Harrison et al. (1990) reported higher NEFA concentrations in wk 1 and 2 postcalving in high-producing cows $(10,800 \mathrm{~kg}$ of $305-\mathrm{d}$ milk yield production; 1.0 and $0.9 \mathrm{mEq} / \mathrm{L}$ NEFA for wk 1 and 2 postcalving, respectively) compared with low-producing cows $(6,900 \mathrm{~kg}$ of $305-\mathrm{d}$ milk yield production; 0.7 and $0.5 \mathrm{mEq} / \mathrm{L}$ NEFA for wk 1 and 2 postcalving). Ospina et al. (2010b) found that primiparous cows with NEFA concentrations $\geq 0.57 \mathrm{mEq} / \mathrm{L}$ and BHBA concentrations $\geq 900 \mu \mathrm{mol} / \mathrm{L}$ within the first 2 wk postcalving had higher 305-d milk yield, although the relationship was reversed in the case of multiparous cows with NEFA $\geq 0.72 \mathrm{mEq} / \mathrm{L}$ and $\mathrm{BHBA} \geq 1,000$ $\mu \mathrm{mol} / \mathrm{L}$. Duffield et al. (2009) also found contradictory results: increased BHBA was associated with decreased 305-d milk production when measured in wk 1 after calving (with an optimal threshold of $\geq 1,800 \mu \mathrm{mol} / \mathrm{L}$ ), but with increased 305-d milk production when measured in wk 2 after calving (with an optimal threshold of $\geq 1,000 \mu \mathrm{mol} / \mathrm{L}$ ). Some of the controversy in the literature could be explained by differences in sampling time and by differences in the inflection point at which fat mobilization stops being beneficial depending on other metabolic and environmental conditions.

On the other hand, high levels of NEFA and BHBA in wk 1 and wk 2 postcalving were associated with milk loss at the first DHIA test, with optimal thresholds within the range of those associated with postpartum disease (LeBlanc et al., 2005; Ospina et al., 2010a; Chapinal et al., 2011) and milk loss (Duffield et al., 2009; Ospina et al., 2010b). Duffield et al. (2009) found that cows with serum BHBA concentrations $\geq 1,400 \mu \mathrm{mol} / \mathrm{L}$ in wk 1 and $\geq 2,000 \mu \mathrm{mol} / \mathrm{L}$ in wk 2 postcalving produced $1.9 \mathrm{~kg}$ and $3.3 \mathrm{~kg}$ less milk, respectively, at first DHIA test. These results suggest that high levels of NEFA and BHBA postcalving are associated with milk loss in early lactation but not necessarily with overall milk loss, which might be explained by the hypothesis that cows with a greater potential to produce milk are at greater risk of ketosis if their greater metabolic, nutritional, or management demands are not met.

No association was found between high serum concentrations of NEFA and BHBA in wk 3 and milk loss at the first DHIA test. These results are not surprising, because NEFA and BHBA concentrations peak in wk 1 and 2 after calving, respectively (Duffield et al., 1998; LeBlanc et al., 2005). This lack of association should be viewed with caution because the sample size in this study decreased substantially in wk 3 and thus, statistical power might have been too low to test the association between the metabolites sampled in that week and milk loss at the first DHIA test.

We found an association between low pre- and postcalving calcium concentrations and milk loss, although the optimal thresholds were within the reference range of 2.1 to $2.8 \mathrm{mmol} / \mathrm{L}$ for the laboratory in which the samples were measured, and within the range (1.64$2.61 \mathrm{mmol} / \mathrm{L}$ ) for cows sampled in the first week after calving with no clinical disease in the transition period (Quiroz-Rocha et al., 2009). Furthermore, the percentage of animals below the threshold was very small in most of the weeks tested. Therefore, results should be interpreted with caution. It is likely that lower calcium concentrations are an indicator of inadequate DMI rather than metabolic disease. 


\section{Pregnancy at the First Al}

Overconditioned cows at calving were more likely to become pregnant at the first AI. This result was unexpected and contributes to the body of variable reports on this question. A meta-analysis (López-Gatius et al., 2003) found no benefit of high BCS at calving for pregnancy at first AI, but a detrimental effect of BCS $<2.5$ at calving. The magnitude of loss of BCS may be a more important predictor of reproductive performance. A review has argued that cows should generally be managed to calve in lean to moderate body condition (Garnsworthy, 2008). In support of other studies, the occurrence of dystocia or clinical disease after calving decreased reproductive efficiency (Berry et al., 2007; Dubuc et al., 2011).

Contrary to our hypothesis, we found no relationship between NEFA and BHBA concentrations around calving and the odds of pregnancy at the first AI. Previous studies reported an association between reproductive efficiency in early lactation and elevated NEFA within 2 wk before calving and elevated NEFA and BHBA within 2 wk after calving (Walsh et al., 2007; Ospina et al., 2010b). Nevertheless, the underlying mechanism through which NEB in the transition period has an effect on reproductive performance some weeks later is unclear. Butler et al. (2006) attributed this delayed effect to increased risk of delayed commencement of ovulation, whereas Leroy et al. (2006) showed a direct toxic effect of NEFA and BHBA on in vitro maturation of oocytes.

An association between low pre- and postcalving calcium concentration and pregnancy at first AI was identified in the current study. Similar to the thresholds found for milk production, the optimal thresholds were within the reference range for the laboratory in which the samples were measured, and the specificity was very low. Therefore, these results should be interpreted with caution.

\section{CONCLUSIONS}

Elevated serum concentrations of NEFA and BHBA and low concentrations of calcium within 1 wk before calving were associated with milk loss through the first 4 DHIA test days. Elevated serum concentrations of NEFA and BHBA in wk 1 and 2 after calving and low concentrations of calcium in wk 1 through wk 3 after calving were associated with milk loss at the first DHIA test. Low calcium concentrations in wk -1 through wk 3 after calving were associated with lower probability of pregnancy at the first AI.

\section{ACKNOWLEDGMENTS}

The authors are grateful to Pfizer Animal Health (New York, NY) for providing financial support for this project. The authors also acknowledge the farmers, veterinarians, and technical staff for their participation in the project. Núria Chapinal was supported by a Beatriu de Pinós postodoctoral grant from the Generalitat de Catalunya.

\section{REFERENCES}

Bauman, D. E., and W. B. Currie. 1980. Partitioning of nutrients during pregnancy and lactation: A review of mechanisms involving homeostasis and homeorhesis. J. Dairy Sci. 63:1514-1529.

Berry, D. P., J. M. Lee, K. A. Macdonald, and J. R. Roche. 2007. Body condition score and body weight effects on dystocia and stillbirths and consequent effects on postcalving performance. J. Dairy Sci. 90:4201-4211.

Butler, S. T., S. H. Pelton, and W. R. Butler. 2006. Energy balance, metabolic status, and the first postpartum ovarian follicle wave in cows administered propylene glycol. J. Dairy Sci. 89:2938-2951.

Carrier, J., S. Stewart, S. Godden, J. Fetrow, and P. Rapnicki. 2004. Evaluation and use of three cowside tests for detection of subclinical ketosis in early postpartum cows. J. Dairy Sci. 87:3725-3735.

Chapinal, N., M. Carson, T. F. Duffield, M. Capel, S. Godden, M. Overton, J. E. P. Santos, and S. J. LeBlanc. 2011. The association of serum metabolites with clinical disease during the transition period. J. Dairy Sci. 94:4897-4903.

Dechow, C. D., and R. C. Goodling. 2008. Mortality, culling by sixty days in milk, and production profiles in high- and low-survival Pennsylvania herds. J. Dairy Sci. 91:4630-4639.

Dohoo, I. R., and S. W. Martin. 1984. Subclinical ketosis: Prevalence and associations with production and disease. Can. J. Comp. Med. 48:1-5.

Domecq, J. J., A. L. Skidmore, J. W. Lloyd, and J. B. Kaneene. 1997. Relationship between body condition scores and milk yield in a large dairy herd of high yielding Holstein cows. J. Dairy Sci. 80:101-112.

Dubuc, J., T. F. Duffield, K. E. Leslie, J. S. Walton, and S. J. LeBlanc. 2011. Effects of postpartum uterine diseases on milk production and culling in dairy cows. J. Dairy Sci. 94:1339-1346.

Duffield, T. F., K. E. Leslie, D. Sandals, K. Lissemore, B. W. McBride, J. H. Lumsden, P. Dick, and R. Bagg. 1999. Effect of prepartum administration of monensin in a controlled-release capsule on milk production and milk components in early lactation. J. Dairy Sci. $82: 272-279$.

Duffield, T. F., K. D. Lissemore, B. W. McBride, and K. E. Leslie. 2009. Impact of hyperketonemia in early lactation dairy cows on health and production. J. Dairy Sci. 92:571-580.

Duffield, T. F., D. Sandals, K. E. Leslie, K. Lissemore, B. W. McBride, J. H. Lumsden, P. Dick, and R. Bagg. 1998. Effect of prepartum administration of monensin in a controlled-release capsule on postpartum energy indicators in lactating dairy cows. J. Dairy Sci. $81: 2354-2361$.

Edwards, J. L., and P. R. Tozer. 2004. Using activity and milk yield as predictors of fresh cow disorders. J. Dairy Sci. 87:524-531.

Ely, L. O., J. W. Smith, and G. H. Oleggini. 2003. Regional production differences. J. Dairy Sci. 86(E. Suppl.):E28-E34.

Garnsworthy, P. 2008. Influences of body condition on fertility and milk yield. Pages 63-72 in Proc. Dairy Cattle Reprod. Counc. Conv., Omaha, NE.

Grummer, R. R. 1995. Impact of changes in organic nutrient metabolism on feeding the transition dairy cow. J. Anim. Sci. 73:2820 2833 . 
Grummer, R. R., and R. R. Rastani. 2004. Why reevaluate dry period length? J. Dairy Sci. 87(E. Suppl.):E77-E85.

Hammon, D. S., I. M. Evjen, T. R. Dhiman, J. P. Goff, and J. L. Walters. 2006. Neutrophil function and energy status in Holstein cows with uterine health disorders. Vet. Immunol. Immunopathol. 113:21-29.

Harrison, R. O., S. P. Ford, J. W. Young, A. J. Conley, and A. E. Freeman. 1990. Increased milk production versus reproductive and energy status of high producing dairy cows. J. Dairy Sci. 73:2749-2758.

Herdt, T. H. 2000. Ruminant adaptation to negative energy balance. Vet. Clin. North Am. Food Anim. Pract. 16:215-230.

LeBlanc, S. J., K. E. Leslie, and T. F. Duffield. 2005. Metabolic predictors of displaced abomasum in dairy cattle. J. Dairy Sci. 88:159-170.

Leroy, J. L., T. Vanholder, G. Opsomer, A. Van Soom, and A. de Kruif. 2006. The in vitro development of bovine oocytes after maturation in glucose and beta-hydroxybutyrate concentrations associated with negative energy balance in dairy cows. Reprod. Domest. Anim. 41:119-123.

López-Gatius, F., J. Yaniz, and D. Madriles-Helm. 2003. Effects of body condition score and score change on the reproductive performance of dairy cows: A meta-analysis. Theriogenology 59:801812.

Losinger, W. C., and A. J. Heinrichs. 1996. Dairy operation management practices and herd milk production. J. Dairy Sci. 79:506514.

Ospina, P. A., D. V. Nydam, T. Stokol, and T. R. Overton. 2010a. Evaluation of nonesterified fatty acids and $\beta$-hydroxybutyrate in transition dairy cattle in the northeastern United States: Critical thresholds for prediction of clinical diseases. J. Dairy Sci 93:546-554.
Ospina, P. A., D. V. Nydam, T. Stokol, and T. R. Overton 2010b. Associations of elevated nonesterified fatty acids and $\beta$-hydroxybutyrate concentrations with early lactation reproductive performance and milk production in transition dairy cattle in the northeastern United States. J. Dairy Sci. 93:1596-1603.

Overton, T. R., and M. R. Waldron. 2004. Nutritional management of transition dairy cows: Strategies to optimize metabolic health. J. Dairy Sci. 87(E. Suppl.):E105-E119.

Quiroz-Rocha, G. F. S. J. LeBlanc, T. F. Duffield, D. Wood, K. E. Leslie, and R. M. Jacobs. 2009. Reference limits for biochemical and hematological analytes of dairy cows one week before and one week after parturition. Can. Vet. J. 50:383-388.

Sheldon, I. M., E. J. Williams, A. N. A. Miller, D. M. Nash, and S Herath. 2008. Uterine diseases in cattle after parturition. Vet. J. $176: 115-121$.

Studer, V. A., R. R. Grummer, S. J. Bertics, and C. K. Reynolds. 1993. Effect of prepartum propylene glycol administration on periparturient fatty liver in dairy cows. J. Dairy Sci. 76:2931-2939.

Walsh, R. B., J. S. Walton, D. F. Kelton, S. J. LeBlanc, K. E. Leslie, and T. F. Duffield. 2007. The effect of subclinical ketosis in early lactation on reproductive performance of postpartum dairy cows. J. Dairy Sci. 90:2788-2796.

Wathes, D. C., M. Fenwick, Z. Cheng, N. Bourne, S. Llewellyn, D. G. Morris, D. Kenny, J. Murphy, and R. Fitzpatrick. 2007. Influence of negative energy balance on cyclicity and fertility in the high producing dairy cow. Theriogenology 68(Suppl. 1):S232-S241.

Wildman, E. E., G. M. Jones, P. E. Wagner, R. L. Boman, H. F. Troutt Jr., and T. N. Lesch. 1982. A dairy cow body condition scoring system and its relationship to selected production characteristics. J. Dairy Sci. 65:495-501. 